\title{
The Significance Key of Intellectual Capital To Increase Financial Performance, Firm's Growth, and Market Value
}

\author{
WAWAN SADTYO NUGROHO* \\ GUDONO \\ Universitas Gadjah Mada
}

\begin{abstract}
The purpose of this study is to examine the contact between intellectual capital and financial performance, firm's growth, and market value also on high-tech industry, low-tech industry, and telecommunication companies. Another contribution of this study is to investigate is there any intellectual capital differences between each company's sectors. Value Added Intellectual capital (VAIC ${ }^{T M}$ ) method by Pulic (1998, $1999,2000,2003)$ is used to verify the effect of intellectual capital on financial performance, firm's growth, and market value. By using purposive sampling method in 5 years period from 2010 to 2014, obtained 45 sample of the high-tech industry, 185 sample of low-tech industry, and 25 sample of telecommunication companies. Partial Least Square (PLS) and one-way ANOVA are used in this study to investigate the empirical causalities of each variable. The results of the analysis indicate that intellectual capital has a positive effect on financial performance. The results also revealed that there are intellectual capital differences in each company's sectors. The results extend the understanding of the role of intellectual capital in creating corporate value and building sustainable competitive advantages for companies in emerging economies, where different technological advancements may bring different implications for the valuation of intellectual capital.
\end{abstract}

Keywords: Intellectual Capital, Financial Performance, Firm's Growth, Market Value, High-Tech Industry, Low-Tech Industry

Intisari: Penelitian ini bertujuan untuk menguji hubungan antara modal intelektual dan kinerja keuangan, pertumbuhan perusahaan, dan nilai pasar juga pada industri teknologi tinggi, industri berteknologi rendah, dan perusahaan telekomunikasi. Kontribusi lain dari penelitian ini adalah untuk menyelidiki apakah ada perbedaan modal intelektual antara masing-masing sektor perusahaan. Nilai Tambah Modal intelektual (VAICTM) metode oleh Pulic (1998, 1999, 2000, 2003) digunakan untuk memverifikasi pengaruh modal intelektual terhadap kinerja keuangan, pertumbuhan perusahaan, dan nilai pasar. Dengan menggunakan metode purposive sampling dalam periode 5 tahun dari 2010 hingga 2014, diperoleh 45 sampel industri teknologi tinggi, 185 sampel industri berteknologi rendah, dan 25 sampel perusahaan telekomunikasi. Partial Least Square (PLS) dan ANOVA satu arah digunakan dalam penelitian ini untuk menyelidiki penyebab empiris dari masing-masing variabel. Hasil analisis menunjukkan bahwa modal intelektual memiliki efek positif terhadap kinerja keuangan. Hasilnya juga mengungkapkan bahwa ada perbedaan modal intelektual di

* Corresponding author: wawan.sn11@gmail.com 
masing-masing sektor perusahaan. Hasilnya memperluas pemahaman tentang peran modal intelektual dalam menciptakan nilai perusahaan dan membangun keunggulan kompetitif yang berkelanjutan bagi perusahaan di negara berkembang, di mana kemajuan teknologi yang berbeda dapat membawa implikasi yang berbeda untuk penilaian modal intelektual.

Kata kunci: Modal Intelektual, Kinerja Keuangan, Pertumbuhan Perusahaan, Nilai Pasar, Industri Berteknologi Tinggi, Industri Berteknologi Rendah

\section{Introduction}

The continuously developed science and technology always give impacts to the companies. Each company must survive among many similar emerged companies, and even each company has to try to be the most superior among the others. Being superior in this case could be superior in product and other competitive advantages. The primary target of the most superior company would be the achievement in economic orientation of the company, which could be measured by company profits.

This condition is consistent with the concept of intellectual capital, where business organizations focused increasingly on the importance of knowledge assets as a form of intangible assets. Edvinsson and Malone (1997) are the researchers who have first discussed IC (Intellectual Capital), which divided the two elements, IC Human Capital and Structural Capital. Edvinsson and Malone (1997) defined Intellectual Capital as a part of Intangible Assets.

Pulic etc. $(1998,2004)$ developed a new method of IC (Intellectual Capital) measurement at Research Center for IC in Austria. The VAIC method developed by Pulic (1998, 1999, 2000, 2003), was designed to provide information about the efficiency of the additional values of the tangible and intangible assets owned by the company. The elements which have formed the IC (Intellectual Capital) included VACA (Value Added of Capital Employed), VAHU (Value Added of Human Capital), and STVA (Structural Capital Value Added). According to Pulic (1998), the primary goal in a knowledge-based economy is to create an additional value of the company, while it needed the right size to create Physical Capital and Intellectual Potential (Potential Capital). VACA is a measure for Physical Capital, while VAHU and 
STVA are the measures of Potential Capital. All of VACA, VAHU, and STVA are internal resources of the company.

Bontis (1998) has also expressed his opinion about the IC component that was consisted of three: Human Capital (HC), Structural Capital (SC), and Relational Capital (RC) or Customer Capital (CC). HC and SC are the internal resources of the company, while the $\mathrm{RC} / \mathrm{CC}$ is a source of power derived from an external company. Bontis (1998) defined IC as a collection or combination of Internal and External Knowledge owned by the company. Pulic (1999) has critiqued the IC component expressed by Bontis (1998). Pulic (1999) has given criticism that the Relational Capital (RC) or Customer Capital (CC) was not an IC component for RC/CC reflecting the company reputation. The company reputation is formed in the external environment (such as trust), it is a side effect of the used IC wisely in the company. It is the underlying reason of Pulic (1999) that the RC/CC is not part of the IC.

Both reasons were still under debate among several researchers who have researched IC until now so that it made the researchers interested in reviewing the IC components. Referring to Edvinsson and Malone (1997), the researcher who first discussed the IC, they have defined Intellectual Capital as a part of Intangible Assets. Therefore, there were some items of Intangible Assets that did not logically contribute as IC parts of a company. One of them was the reputation of the company (RC/CC), that might be a side effect of the used IC wisely in the company according to Pulic (1999). Based on this, the researchers have tried to use the IC components developed by Pulic (1998, 1999, 2000, 2003).

They were already performed several studies on the effect of intellectual capital to the company. Mr. Wang's research (2011) has used the model Pulic (VAICTM) to study the relationship between intellectual capital and financial performance, which the result showed that intellectual capital had the positive effect on firm performance. Whereas the research conducted by Gan and Saleh (2008) on Bursa Malaysia Securities showed that intellectual capital (VAICTM) was associated positively with the company performance and the market value. 
The research conducted by Muhammad (2009) in the Malaysian financial sector has also proved a similar thing that the intellectual capital had positive and significant effects to the company performance as measured by profitability and Return on Assets (ROA). It was conducted for several times the research on intellectual capital in Indonesia, one of them was performed by Ulum et al. (2008), which proved that: first, intellectual capital (VAIC ${ }^{\mathrm{TM}}$ ) affected the financial performance of the company; second, intellectual capital (VAIC ${ }^{\mathrm{TM}}$ ) effected on the future of financial performance of the company; and the third, ROGIG did not affect the future of the financial performance of the company.

In contrast to the mentioned studies, the research of Mosavi et al. (2012) and Kuryanto (2008) showed the inversed results, i.e., there was not any positive influence between intellectual capital and financial performance of the company. Based on the study result that was contradictive, it was interesting to be reexamined by researching intellectual capital. This research bas ded on the study undertaken by Solikhah et al. (2010). The differences of this study with the Sholikhah research (2010) were: first, this study puts into the entire cost of employees to calculate VAHU because the previous studies included only salaries and wages for the reason of IC concept considered the cost expenditures incurred by the company that was viewed as an investment of actual company with the hope of obtaining the additional value for the company in the future. Second, this study used to sample data of companies of the high-tech industry, low-tech industry, and services, especially telecommunications for all categories of the companies must have a company in managing different resources such as activities of $\mathrm{R} \& \mathrm{D}$ costs.

The previous research was performed only on manufacture companies; third, the indicators of firm size were added to the variable of the financial performance. Size indicator was added as a control variable to the financial performance of big and small companies because it was worried that the company size also influenced the financial performance of the company. Fourth, this study examined also specifically the effect of intellectual capital to the industrial manufacturing based on high technology and the companies that did not use high technology (low tech), and service companies, 
because we believed that the technology application in manufacturing and service companies would be different results in the use of intellectual capital.

\section{Theoretical Framework and Hypothesis Development}

Pulic (1998; 1999; 2000, 2003) did not measure directly the company intellectual capital, but he has filed a measure to assess the efficiency of the additional values as a result of the company intellectual ability (Value Added Intellectual Coefficient VAIC $\left.^{\mathrm{TM}}\right)$. The main components of VAIC ${ }^{\mathrm{TM}}$ could be viewed on the company resources: physical capital (value added capital employed - VACE), human capital (value-added human capital - VAHC), and structural capital (structural capital value added - VASC).

Value Added of Capital Employed (VACA) is an indicator of the VAIC'M used to measure the additional values created by the use of a unit of physical capital. Pulic (1998) said that any use of a unit of CE (Capital Employed) had generated higher profits than other company, it meant that the company was better in using its CE. Better use of CE is a part of the company intellectual capital (IC). Value Added Human Capital (VAHU) showed how many values added (VA) that could be produced with the spent funds on the workers. The relationship between VA with human capital (HC) indicated the ability to create value in the company.

Structural Capital Value Added (STVA) showed the structural capital (SC) contribution in creating values. STVA measured the number of the required SC to produce 1 rupiah of VA and was an indication of the SC success in creating values. $\mathrm{SC}$ was not an independent measure as $\mathrm{HC}$ in the process of creating values. It meant that the higher the contribution of $\mathrm{HC}$ in value creation, the smaller the contribution of $\mathrm{SC}$ in this regard. Furthermore, Pulic stated that the SC was VA minus HC.

The companies that could manage their intellectual resources is believed to be able in creating value-added which leads to making competitive advantage by conducting innovation, research, and development with the purpose of improving the financial performance of the company. The company financial performance is a display or a wholly financial state of the company during a specified period. It is 
similar to the concept of Resource-Based Theory that is created by the idea of Wernerfelt in 1984 and developed by Jay B. Barney in 1986. In the context of explaining the influence of intellectual capital on the financial performance, the growth and market value of the company, Wernerfelt explained that according to the Resource-Based Theory, a company would gain a competitive advantage and an excellent financial performance by possessing, controlling, and using the essential strategic assets. The strategic assets include tangible and intangible assets (Barney Clark, 2007).

The similar thing was stated by Belkaoui (2003), according to Resource-Based Theory the company resources are critical drivers of competitive advantage and firm performance. Also, it was said that in achieving the sustainable profits a company must be able to control the tangible and intangible assets. According to Gan and Saleh (2008), the definition of intellectual capital is intellectual matter, such as good knowledge, information, intellectual property, an experience that could be used to produce the wealth of the company.

Whereas from the viewpoint of Stakeholder Theory it is stated that the corporate managers would attempt to get value added which would then be redistributed to all stakeholders. This theory maintained the relationship of the stakeholders including all forms of the relationship between the company and all stakeholders. According to Fontaine et al. (2006), the stakeholder approach was appeared firstly and was developed by Freeman in 1984. Based on stakeholder theory, organizational management is expected to perform the essential activities by stakeholders and for reporting back on those activities to the stakeholders. In context to explain the relationship between VAICTM and financial performance, firm's growth, and market value, the stakeholder theory is viewed by the two fields, both in ethics (moral) and managerial fields.

Ethics field argues that all stakeholders have rights to be treated fairly by the organization, and managers should manage an organization for the benefit of all stakeholders (Deegan, 2004). Whereas managerial fields found that the stakeholder's strength in influencing corporate management should be regarded as a function of the 
stakeholder control level over the resources needed by the organization (Ulum et al., 2008). The researcher used Stakeholder Theory in this study because in theory it is expected that the manager would be able to manage the use of IC wisely and consider the stakeholder's interests so that it could improve financial performance, growth, and market performance of the company.

Most of the study results, such as research Wang (2011), Muhammad (2009), and Mosavi et al. (2012) and Chen et al. (2005) showed that the Intellectual capital affected positively to the financial performance. Similarly, the research of Solikhah et al. (2010) which proved empirically that the intellectual capital affected positively to the firm's performance. Financial performance is often considered in determining the investor choices to invest. A company with the capability to leverage its intellectual resources optimally could be seen on its financial performance. It meant that the capital invested by the investor could be used optimally so that it could increase the company revenue.

The study results conducted by Mosavi et al. (2012) provided empirical evidence that intellectual capital could influence the growth (in this case measured by sales growth). Although in the study sales growth is an indicator of the company performance. Then, the study conducted by Solikhah et al. (2010) has also shown that intellectual capital was proved significantly to the company growth. The companies with optimal utilization of intellectual capital will create value-added regularly and continuously so that the company will be able to grow and survive.

Based on the study results of Mosavi et al. (2012), it has noted that the investors were likely to pay a higher rate on the shares of companies with the intellectual resources compared to the companies with low intellectual resources. The paid price of the investor reflected the company value. Market value was happened due to the inclusion of the concept of intellectual capital that was the main factors and could increase the company value. The previous study that was also conducted by Chen $e t$ al. (2005) and Mosavi et al. (2012) noted that intellectual capital had a positive effect on the market value. Along with the development of knowledge-based industries, the investors would not only focus on short-term interests to improve the financial return. 
Also, the investors would also give more votes to the companies with high intellectual resources.

The empirical studies of Pulic (2000) found that it was different the intellectual capital contribution to each industry. In the industries of drilling and mining, valueadded showed a slightly higher value than the expenditure for employees with the relatively insignificant components of structural capital. Whereas in the pharmaceutical industry, the most significant contribution in providing value-added was structural capital. Pulic opinion was supported by the evidence of Tan et al. (2007) who found that the intellectual capital contribution to the company performance was different for each industry. The research of Solikhah et al. (2010) also provided empirical evidence that the contribution of intellectual capital to the company was different for each industry.

Figure 1

The framework of Research Model

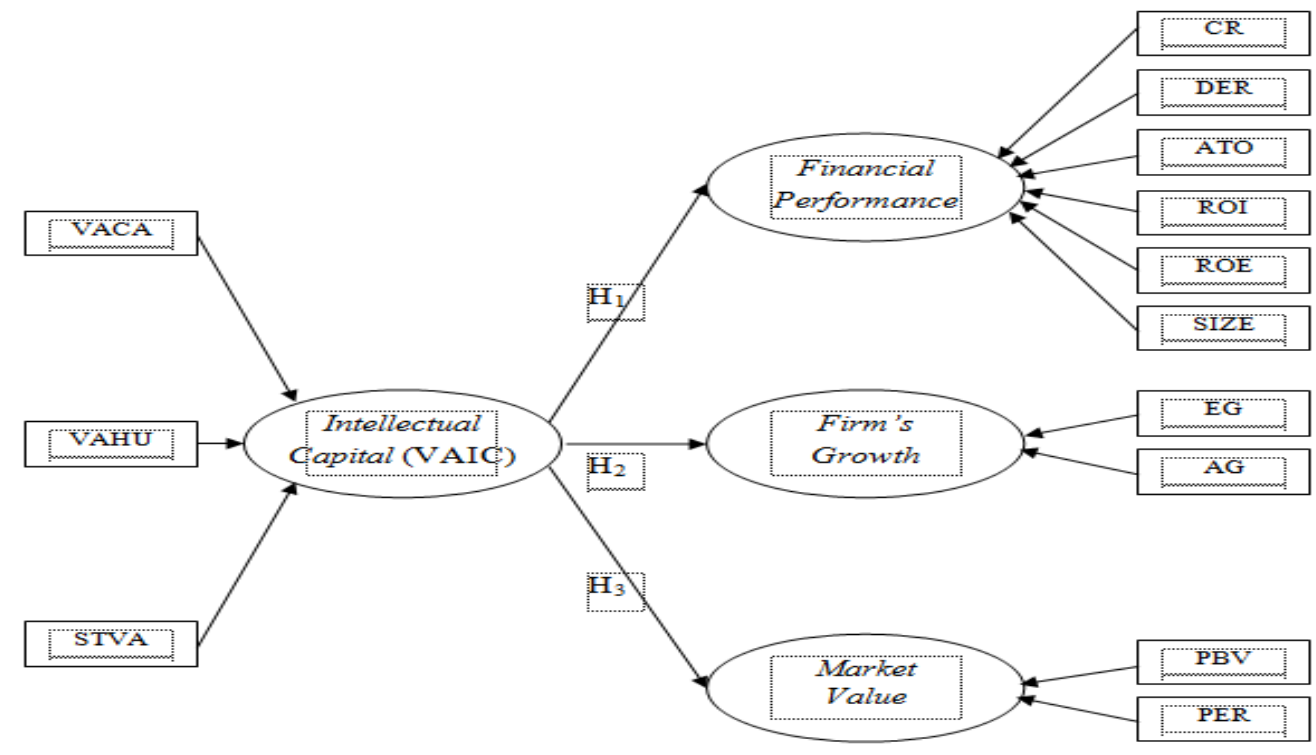

Based on the theories and previous studies, several hypotheses could be proposed such as follows: 
$\mathrm{H}_{1}$ : Intellectual capital has a positive effect on the Financial Performance.

H2: Intellectual capital has a positive effect on the Firms Growth.

H3: Intellectual capital has a positive effect on the Market Value.

H4: The Intellectual capital performance is different for each company sector (High-

Tech Industry, Low-Tech Industry, and Telecommunications Services Company).

\section{Research Method}

\subsection{Population and Sample}

The population in this study consisted of the manufacturing and telecommunications services companies in Indonesia. The samples were several manufacturing companies and telecommunication services companies that have made go public in Indonesia Stock Exchange (BEI) during 2010, 2011, 2012, 2013, and 2014. The selection of manufacturing sector as a sample was referred to the research of Solikhah et al. (2010), except that this study examined specifically the manufacturing companies classified as high tech and low-tech industries. Previously, the research of Gan and Saleh (2008) performed a study on manufacturing companies that implemented the ICT (Information and Communication Technology) development, so that it tried to retest the similar samples that were grounded in how intense the kind of research and development by cost R \& D companies. Every manufacturing company needs undoubtedly the activities of $R \& D$, especially for manufacturing companies of high-tech. Therefore, this study divides manufacturing companies into high-tech and low-tech industries based on Short-Term Business Statistics (STS, 2013) of the EU-27's industrial growth.

The service companies that would be used as samples came from the telecommunications services companies with the consideration that the field of telecommunications services companies has high activities of $\mathrm{R} \& \mathrm{D}$ in supporting business continuity.

The samples selection in this study used a method of purposive sampling. The research samples were based on the determined criteria such as the followings: 
1. Representing industries that included in high-tech industry, low-tech industry, and the telecommunications services company.

2. Not delisting (exit) from the Indonesia Stock Exchange for five years respectively: 2010, 2011, 2012, 2013, and 2014.

3. The company has performed listing at Indonesia Stock Exchange before 2010.

4. The company is not suspended from trading in 2010, 2011, 2012, 2013, and 2014.

5. Each annual report has the completeness of information to meet the interests of measuring each variable.

\subsection{Variable Measurement}

\subsubsection{Independent Variables: Intellectual Capital}

The performance of intellectual capital is value creation obtained for intellectual capital management. The performance of intellectual capital here is measured by value added created by physical capital (VACA), human capital (VAHU), and structural capital (STVA). The combination of the three value added is symbolized by the name of VAICTM that is developed by Pulic $(1998 ; 1999 ; 2000)$ with the following measurements:

$$
\begin{aligned}
& \mathrm{VACA}=V A / C E \\
& \mathrm{VAHU}=V A / H C \\
& \mathrm{STVA}=S C / V A
\end{aligned}
$$

Note:

Value Added (VA): The difference between Output and Input

$\mathrm{VA}=\mathrm{OUT}-\mathrm{IN}$

Output (OUT): Total sales and other revenue

Input (IN): $\quad$ Costs and expenses (other than personnel expenses)

Human Capital (HC): Personnel costs

Capital Employed (CE): Available funds (equity, net income)

Structural Capital (SC): the difference between value added and human capital

$\mathrm{SC}=\mathrm{VA}-\mathrm{HC}$ 


\subsubsection{Dependent Variables:}

\section{Financial Performance (FP)}

The first dependent variable in this research is financial performance (FP), then measured by the indicators of Current Ratio (CR), Debt to Equity Ratio (DER), Assets Turnover (ATO), Return on Investment (ROI), Return on Equity (ROE ), and Company Size (SIZE).

$$
\begin{aligned}
& \text { CR }=\frac{\text { current assets }}{\text { current flabilfttes }} \\
& \text { DER }=\frac{\text { total debt }}{- \text { shareholders equity }} \\
& \text { ATO }=\frac{\text { Sales }}{\text { total } \text { assets }} \\
& \text { ROI }=\frac{\text { Net earning }}{\text { Total Assets }} \\
& \text { ROE }=\frac{\text { Net Earning }}{\text { shareholders equity }} \\
& \text { SIZE }=\text { Ln Total Asset }
\end{aligned}
$$

\section{Firm's Growth (GR)}

The variable of company growth is proxied by the two indicators: Earning Growth (EG) and Asset Growth (AG).

$$
\begin{aligned}
& \mathrm{EG}=\frac{\text { earning of year }}{\mathrm{t}}-1 \times 100 \% \\
& \text { earning of year } \mathrm{t}_{\mathrm{t}-1}
\end{aligned}
$$

Firms' Market Value (MV)

The variable of firms' market value (MV) is proxied by Price to Book Value ratio (PBV) and Price to Earnings Ratio (PER).

$$
\mathrm{PBV}=\frac{\text { Market Price }}{\text { Book value per share }}
$$




$$
\mathrm{PER}=\frac{\text { Stock Price }}{\text { Earning per share }}
$$

\subsection{Method of Data Analysis}

The used methods of data analysis in this research included descriptive statistical analysis and one-way ANOVA using SPSS V.21. Also, this research used a measurement of test model (Outer Model) and test of structural model (Inner Model) using WarpPLS 3.0. The selection of the PLS method was based on the consideration that in this study all of the variables in the model were latent variables formed with formative indicators. PLS was a suitable technical choice because of its small sample size and normally attribute variable.

Descriptive statistics were used to determine the value of the maximum, minimum, average, and standard deviation of each variable (Ghozali, 2012: 19). Stevens (2013) stated that the purpose of the one-way ANOVA test was to determine whether the average value of the dependent variable was different or not. Based on Stevens (2009), Montgomery (2013), and also Ghozali (2013: 71), decision-making on this analysis used multiple stages, Test of Homogeneity Variance to test if a variable had a same variance, Test of between-subject effects that would indicate the different performance of Intellectual capital for each company sector, Post Hoc Test that would determine which variables that contributed to make a difference (Stevens, 2009: 151), and Homogeneous Subset that would determine the differences or similar in the average value of the variables.

Testing with PLS was conducted to evaluate $\mathrm{H} 1, \mathrm{H} 2$, and $\mathrm{H} 3$ by using the entire samples based on Jogiyanto (2011: 82). Test of measurement model used to validate the built research model. In this study, it could not be conducted the reliability test because each formative indicator in a latent variable were assumed to be correlated (independent), so that the reliability value could not be fixed (Jogiyanto, 2011: 93). Then, a test of the structural model (Inner Model) was performed to predict the causal relationships among variables or test of the hypothesis. The output model is the most significant output results in the decision-making test with PLS. The output model would provide the resumed information about the research model, and the value of 
testing results of $R$ squared value, the value of path coefficient (value of coefficient $\beta$ ), and $p$-value in the form of picture researching model.

\section{Results and Discussion}

\subsection{Empirical Results}

The tabulation results from sample selection of the overall company population and the used consideration could be tabulated in Table 1.

Table 1

Sample Distribution Company

\begin{tabular}{|c|c|c|c|c|c|}
\hline \multirow[b]{2}{*}{ No. } & \multirow[b]{2}{*}{ Description } & \multicolumn{3}{|c|}{ Total } & \multirow[b]{2}{*}{ Integration } \\
\hline & & $\begin{array}{l}\text { High-tech } \\
\text { Industry }\end{array}$ & $\begin{array}{l}\text { Low-tech } \\
\text { Industry }\end{array}$ & $\begin{array}{c}\text { Telecommunication } \\
\text { Service }\end{array}$ & \\
\hline 1 & Number of companies & 11 & 47 & 6 & 64 \\
\hline \multirow[t]{2}{*}{2} & $\begin{array}{l}\text { Not delisting (exit) on } \\
\text { Indonesia Stock } \\
\text { Exchange for five years } \\
\text { respectively: } 2010 \text {, } \\
2011,2012,2013 \text {, and }\end{array}$ & & & & \\
\hline & 2014. & 0 & 0 & 0 & 64 \\
\hline \multirow[t]{2}{*}{3} & $\begin{array}{l}\text { The company has } \\
\text { performed listing at }\end{array}$ & & & & \\
\hline & $\begin{array}{l}\text { Indonesia Stock } \\
\text { Exchange before } 2010 .\end{array}$ & (1) & (5) & 0 & (6) \\
\hline \multirow[t]{2}{*}{4} & $\begin{array}{l}\text { The company is not } \\
\text { suspended from trading } \\
\text { in } 2010,2011,2012 \text {, } \\
2013 \text {, and } 2014 \text {. }\end{array}$ & & & & \\
\hline & & 0 & 0 & (1) & (1) \\
\hline 5 & & (1) & (5) & 0 & (6) \\
\hline \multicolumn{2}{|c|}{ Total } & 9 & 37 & 5 & 51 \\
\hline \multicolumn{2}{|c|}{ Total in Five Years } & 45 & 185 & 25 & 255 \\
\hline
\end{tabular}

Hypothesis Testing used PLS (Partial Least Square) such as follows:

\section{Outer Model Testing}

After it was conducted outer model testing, it was known that not all indicators met the eligibility assumption so that some indicators have been removed. Similarly, the outer model testing was performed on each sample of the company. 


\section{Inner Model Testing}

Before conducting Inner Model testing, the researchers first saw the goodness of fit of the proposed model. According to Sholihin (2013: 61), the output of general result would show the part of model fit indices and $P$ values by the results of the three indicators of fit: average path coefficient (APC), average R-squared (ARS), and average variance inflation factor (AVIF). This study was conducted to evaluate among the latent variables (strictly confirmatory) so that the model indicator of fit would become less critical. This research would still provide the test results to support the analysis, which is presented in Table 2 that showed a summary of general output. It indicated that the performed testing model would be qualified for the goodness of fit.

After the goodness of fit has been qualified, the Table 2 proved that the IC had a positive influence on the FP with $p$-value $<0.01$ and $\beta=0.53 . \mathrm{R}^{2}$ of 0.28 indicated that the variable of intellectual capital was able to explain $28 \%$ variable of financial performance, while other factors outside the research model explained the remaining $72 \%$. The increased Intellectual capital would affect the also increased financial performance, with the effect of $0.53(\beta=0.53)$. P-value of 0.24 indicated that intellectual capital (IC) had not any effect on the firm's growth $(\mathrm{GR})$. Beta values showed 0.11 , and $\mathrm{R}^{2}$ value showed 0.01 . Based on these results, it could be known that the IC was not able to explain the variable of GR because $R$ square showed very little value, which was only $1 \%$. It was proved that the IC did not affect to market value with a $p$-value of 0.11 and $\mathrm{R}^{2}$ of 0.01. Beta value also showed the smallest value among other things, that was only 0.08 .

Table 2

Summary of Output General Result

\begin{tabular}{c|cc|c|cc|cc}
\hline & \multicolumn{2}{|c|}{$\begin{array}{c}\text { High-tech } \\
\text { Industry }\end{array}$} & \multicolumn{2}{c|}{$\begin{array}{c}\text { Low-tech } \\
\text { Industry }\end{array}$} & \multicolumn{2}{c}{$\begin{array}{c}\text { Company of } \\
\text { Telecommunication } \\
\text { Service }\end{array}$} & \multicolumn{2}{|c}{ Integration } \\
\cline { 2 - 6 } & $\begin{array}{c}\text { Model } \\
\text { Fit } \\
\text { Indices }\end{array}$ & $\begin{array}{c}\text { Model } \\
\text { value }\end{array}$ & $\begin{array}{c}\text { Fit } \\
\text { Indices }\end{array}$ & $\begin{array}{c}\text { Model } \\
\text { value } \\
\text { Fit } \\
\text { Indices }\end{array}$ & $\begin{array}{c}\text { Model } \\
\text { Fit } \\
\text { Indices }\end{array}$ & $\begin{array}{c}\text { p- } \\
\text { value }\end{array}$ \\
\hline
\end{tabular}




\begin{tabular}{l|lc|cc|cc|cc}
\hline APC & 0.526 & $<0.001$ & 0.334 & $<0.001$ & 0.660 & $<0.001$ & 0.239 & $<0.001$ \\
ARS & 0.324 & 0.006 & 0.141 & 0.248 & 0.449 & 0.015 & 0.100 & 0.021 \\
AVIF & 1.000 & $<5$ & 1.000 & $<5$ & 1.000 & $<5$ & 1.000 & $<5$ \\
\hline Note & Values of APC, & Values of APC & Values of APC, & Values of APC, \\
& ARS, and AVIF & and AVIF have & ARS, and AVIF have & ARS, and AVIF \\
& have qualified to & qualified to the & qualified to the & have qualified to \\
& the goodness of & goodness of fit & goodness of fit & gooss of \\
& fit & & & & & \\
\hline
\end{tabular}

Testing of the inner model also performed on each sample of companies. The variable of intellectual capital always produces a $p$-value that is significant to the variable of Financial Performance, either in the type of high-tech industry companies, low-tech industry companies, and the telecommunications services companies and the integration of $<0.001 ; 0,013 ;<0.001$; and $<0.001$. Whereas the influence of intellectual capital variable to the variables of Firm's Growth and Market Value still shows the inconsistent results. The impact of intellectual capital to the firm's growth and market value was partial, only on a specific type of the company.

\section{One Way ANOVA Testing}

SPSS output of one way ANOVA showed that there were differences in intellectual capital (VACA and STVA) among types of the companies. The value of the adjusted $\mathrm{R}^{2}$ of 0.058 meant that the variability of company types could explain VACA variability by $5.8 \%$. The value of the adjusted $\mathrm{R}^{2}$ also showed that the variability of the company types was able to explain the STVA variability of $15.2 \%$. Whereas the indicator of VAHU was proved to be similar among company types with the adjusted $\mathrm{R}^{2}$ that also showed the value of 0.000 , it meant that the influence of the company against VAHU was minimal.

\subsection{Discussion}

\subsubsection{Effect of Intellectual Capital on Corporate Financial Performance (Financial Performance)}

This study has proved that the IC effected positively to the financial performance so that it was accepted the first hypothesis (H1). It means that the higher the value of 
intellectual capital the higher the value of the financial performance of the company. It applies to the companies with high-tech industry, low-tech industry, and telecommunications services (not affected by other factors).

This finding supports empirically the stakeholder theory in which the stakeholders will play a role in the management of intellectual resources of the company to create a value-added and competitive advantage. A company with the capability to leverage its intellectual resources optimally could be seen on its financial performance. These study results have also reinforced the resource-based theory, that meant that the capital invested by the investor could be used optimally so that it could increase the company revenue. The study results are consistent with the research conducted by Mr. Wang (2011) about the listed companies in Taiwan Economic Journal Database and Baroroh (2013) who has researched banking company in Indonesia that stated that intellectual capital was proved to have a significant and positive effect on the financial performance of the company.

\subsubsection{Effect of Intellectual Capital on Company Growth (Firm's Growth)}

Based on the test results, it was obtained that IC did not affect the company growth, it meant that the increased company growth was not affected by the also increased Intellectual capital.

The study results were not yet able to support the stakeholder theory and RBT where the companies with the capability to utilize the intellectual resources effectively and efficiently would encourage the development capabilities of the company. These findings indicated two possibilities. First, the company has minimum knowledge of intellectual capital so that it could not be utilized optimally.

The second is the intellectual capital will only give effect to the firm's growth just in certain companies, because in this study it was also noted that the intellectual capital positively affected to the firm's growth in companies with high technology. The higher the used technology in a company, the more optimal the use of the intellectual resources. 
These results were contradictive with the study results of Solikhah et al. (2010) that showed that the Intellectual capital was proved significant to the company growth. The study results were corroborated contradictive with some of the other studies results such as the study of Mosavi et al. (2012) that provided empirical evidence that the Intellectual Capital (VAIC ${ }^{\mathrm{TM}}$ ) has affected on the growth (in this case measured by sales growth). It could be proved that the model has not been a comprehensive study because it only used two indicators in assessing the firm's growth: earnings growth and asset growth. The use of more than two indicators might improve the research model, such as indicators of revenue growth that was performed by Mosavi et al. (2012) in his research. According to Mosavi et al. (2012), growth revenues is the most straightforward measurement indicating the growth of an organization.

\subsubsection{Effect of Intellectual Capital on the Market Value of the Company (Firm's Market Value)}

This study showed that the IC did not affect to company's market value. It meant that the increased market value of the company was not influenced by the also increased Intellectual capital. The study result was appropriate with the result of Gan and Saleh (2008) which stated that the VAIC was not able to explain the company value. These findings indicated that market appreciation of a company was based on the owned physical resources, and the investors were not focused on the intellectual resources of the company. It was suggested from the fact that the intellectual capital has not become an interesting theme to be developed in creating value for the company. The investors are still not focused on long-term interests but only focus on improving the financial returns. It was not certainly appropriate with the theory of RBT.

The different results were proposed by Chen et al. (2005) which stated that intellectual capital had a positive impact on the market value. This study used only two indicators to describe the value of the company: price to book value ratio and price-to-earnings ratio. Even if it was based on the testing results of the outer 
model, it was also known that the indicator of price to earnings ratio was not feasible, in other words, the variable market value was only represented by the indicator of price to book value ratio. It indicated that the indicator of price to book value ratio was less representative so that in the next study it could add other indicators such as annual stock return.

\subsubsection{There Is A Difference of Intellectual Capital Performance in Each Sector of The} Company.

Each type of company would have a different focus of interest so that the utilization of its resources would also be different. It is reinforced by Pulic opinion (2000) in his research that found that the contribution of each industry to the Intellectual capital is distinct.

The test results showed that the type of company had marginal and significant effects on the intellectual capital in the companies of telecommunications services, high-tech industry, and low-tech industry. It meant that these types of companies would affect marginally to some components of intellectual capital: VACA and STVA, whereas the other types did not affect VAHU. The test results of this study supported Solikhah et al. (2010) who found that the Intellectual capital contribution on the performance of different companies was different for each industry.

The findings of the research can illustrate how good is the circumstance of industry in Indonesia, where the majority is still many companies that rely on human capital.

\section{Additional Discussion}

Table 3

Output Test Results Summary

\begin{tabular}{|c|c|c|c|c|c|c|c|c|c|c|c|c|c|}
\hline & & & $\begin{array}{l}\text { High-Te } \\
\text { Indust }\end{array}$ & & & $\begin{array}{l}\text { Low-Te } \\
\text { Indust }\end{array}$ & & Telecon & nmunicat & tion Service & & tegratic & \\
\hline & & FP & GR & $\mathrm{MV}$ & FP & GR & MV & FP & GR & $\mathrm{MV}$ & FP & GR & $\mathrm{MV}$ \\
\hline & $p$-value & $<0.001^{* * *}$ & $0.086^{*}$ & $<0.001^{* * *}$ & $0.013^{* *}$ & 0.210 & $0.102^{*}$ & $<0.001^{* * *}$ & 0.187 & $<0.001^{* * *}$ & $<0.001^{* * *}$ & 0.244 & 0.111 \\
\hline IC & Koef. $\beta$ & 0.769 & 0.237 & -0.570 & 0.557 & 0.144 & 0.302 & 0.745 & -0.499 & 0.711 & 0.530 & 0.111 & 0.076 \\
\hline & $R^{2}$ & 0.592 & 0.056 & 0.325 & 0.310 & 0.021 & 0.091 & 0.555 & 0.249 & 0.506 & 0.281 & 0.012 & 0.006 \\
\hline
\end{tabular}


Note:

${ }^{* * *}$ significant at $1 \%$

${ }^{* *}$ significant at $5 \%$

* marginal significance at $10 \%$

The conducted tests on the sample of a company with high-tech industry, lowtech industry, and the telecommunications company proved that the intellectual capital positive effected on financial performance. This is supported by research of Wang (2011) which stated that the intellectual capital influenced significantly to the company's performance. Whereas the variable of firm's growth that was appeared to be affected by the intellectual capital could only be proven in testing by samples of companies with high-tech industry. These results indicated a considerable influence on the utilization of intellectual capital in the company with high-tech industry. The companies of high-tech industry have utilized components of the resources including physical capital and intellectual potential to improve the company's growth. The average value of VACA and STVA owned by telecommunications services company was similar with the low-tech industry companies, and it meant that the telecommunications services companies were still not able to optimize the available funds and structural capital in the company. Inversely, the research of Gan and Saleh (2008) showed that the intellectual capital was able to explain the company growth using the company's productivity indicators in this case.

The different result occurred in the testing of intellectual capital effect on the market value where the intellectual capital was proved to have affected negatively to the market value with a $\beta$ coefficient of -0.57 . IC was also shown to have impacted positively on a sample of companies with low-tech industry and telecommunications services. These results are supported by the study results of Chen et al. (2005), which proved that intellectual capital affected positively to the firm's market value. The possible reasons that could underlie this condition was the difference in the management of value-added capital employed (VACA) and structural capital value added (STVA) such as could be seen in the one-way ANOVA test. Therefore, it could be assumed that the companies of low-tech industry are still not able to optimize the 
available funds and structural capital in the companies so that it has not been optimal the impact on the growth of the company.

\section{Conclusion and Limitation}

It could be concluded from the results of hypothesis testing that the intellectual capital has a positive impact on financial performance. Whereas on the other hand, it could be concluded that the intellectual capital has not any effect on the firm's growth and market value. One-way ANOVA test could conclude that there were differences in the performance of intellectual capital of each company.

The values of adjusted $\mathrm{R}^{2}$ of 0.28 indicated that the variable of financial performance could be explained by the variable of intellectual capital of $28 \%$, whereas other factors explained the remaining $72 \%$ in outside of the research model. The test results of one-way ANOVA showed that the company types influenced VACA indicators and STVA company. The number of adjusted $\mathrm{R}^{2}$ of 0.058 on testing among types of companies towards intellectual capital (VACA) meant that the variability of company types could explain the variability by $5.8 \%$. Whereas the value of adjusted $R$ squared on testing the company types to the STVA indicators also showed that the variability in the company types could explain the STVA variability of $15.2 \%$.

It could be conducted further research by expanding the scope of the study, such as by adding objects like corporate banking services that indeed mainly utilized their human resources, so that it could be seen differently with the manufacturing companies. It would be better if the further research could add indicators of Annual Stock Return (ASR) in the variable of market value.

The indicators addition should also be conducted at the variable of firm's growth, such as by adding indicators of growth revenue. The further researches could also deepen the testing of the influence of company types by using two-way ANOVA analysis to know the influence of company types to the intellectual capital on the dependent variable. Then, it should be performed the hypothesis addition to analyze the test results in more detail. 


\section{REFERENCES}

Barney, Jay B. dan Delwin N. Clark. 2007. Resource-Based Theory: Creating And Sustaining Competitive Advantages. (Online), (http://http://www.slideshare.net) accessed 19 June 2015 .

Baroroh, Niswah. 2013. Analisis Pengaruh Modal Intelektual Terhadap Kinerja Keuangan Perusahaan Manufaktur Di Indonesia. Jurnal Dinamika Akuntansi. Vol. 5 No.2 pp. 172 182.

Belkaoui, A.R. 2003. Intellectual Capital and Firm Performance Of Us Multinational Firms: A Study Of The Resource-Based And Stakeholder Views. Journal of Intellectual Capital. Vol. 4 No. 2. pp. $215-226$

Chen, M.C., S.J. Cheng, Y. Hwang. 2005. An Empirical Investigation Of The Relationship Between Intellectual Capital And Firms' Market Value and Financial Performance. Journal of Intellectual Capital. Vol. 6 NO. 2. pp. 159-176.

Deegan, C. 2004. Financial Accounting Theory. McGraw-Hill Book Company. Sydney.

Fontaine, Charles, et al. 2006. The Stakeholder Theory. (Online), (http://www.martonomily.com) accessed 19 June 2015.

Gan, Kin and Zakiah Saleh. 2008. Intellectual Capital and Corporate Performance of Technology-Intensive Companies: Malaysia Evidence. Asian Journal of Business and Accounting, 1(1), 2008, 113-130.

Gudono. 2012. Analisis Data Multivariat. BPFE-UGM: Yogyakarta. . 2013. Aplikasi Analisis Multivariate dengan Program IBM SPSS 21 Update PLS Regresi. Badan Penerbit Undip: Semarang.

Jogiyanto. 2011. Konsep dan Aplikasi Structural Equation Modeling Berbasis Varian Dalam Penelitian Bisnis. STIM YKPN: Yogyakarta.

Kuryanto, Benny et al. 2008. Pengaruh Modal Intelektual terhadap Kinerja Perusahaan. SNA XI. Pontianak.

Kusumo, Bambang Parto. 2012. Studi Empiris Pengaruh Modalintelektual Terhadap Kinerja Keuangan, Pertumbuhan Perusahaan, dan Nilai Pasar Pada Perusahaan Yang Terdaftar Di Bursa Efek Indonesia (BEI). Skripsi: Fakultas Ekonomika dan Bisnis Program Studi S1 Akuntansi Universitas Diponegoro.

Molodchik, Mariya Anatolievna et all. 2012. Intellectual Capital Transformation Evaluation Model. Journal of Intellectual Capital. Vol. 13.

Montgomery, Douglas C.. 2013. Design and Analysis of Experiments Eighth Edition. John Wiley \& Sons, Inc.: United States. 
Mosavi, Seyed Alireza, Shekoufeh Nekoueizadeh and Mahnoosh Ghaedi. 2012. A Study of Relations Between Intellectual Capital Components, Market Value, and Finance Performance. African Journal of Business Management. Vol. 6 (4), pp. 1396-1403,1 February 2012.

Wang, Mu Shun. 2011. Intellectual Capital and Firm Performance. Annual Conference on Innovations in Business \& Management London, UK.

Muhammad, Nik Maheran Nik. 2009. Intellectual Capital Efficiency and Firm's Performance: Study on Malaysian Financial Sectors. International Journal of Economics and Finance. Vol. 1 No. 2 pp. 206-212.

Nasrullah, Muh. 2011. Anova Satu Jalan (One Way ANOVA ) dengan SPSS. (Online), (HTTP:// www.paknasir.info.) accessed 19 March 2016.

Pulic, A. 1998. Measuring the Performance Of Intellectual Potential In Knowledge Economy. Paper presented at the 2nd McMaster Word Congress on Measuring and Managing Intellectual Capital by the Austrian Team for Intellectual Potential.

1999. Basic information on VAIC ${ }^{\text {TM }}$ (Online), (http://www.vaic-on.net.) diakses 20 February 2016.

. 2000. VAICTM - an accounting tool for IC management. (Online), (http://www.measuring-ip.at/Papers/ham99txt.htm) accessed 20 February 2016.

Short-Term Business Statistics. 2013. High-technology Versus Low-technology Manufacturing. (Online), (http://ec.europa.eu/eurostat/statistics-explained/index.php.) accessed 6 November 2015

Sholihin, Mahfud dan Dwi Ratmono. 2013. Analysis SEM-PLS Dengan WarpPLS 3.0 Untuk Hubungan Nonlinear Dalam Penelitian Sosial dan Bisnis. Andi Yogyakarta: Yogyakarta.

Solikhah, Badingatus et al. 2010. Implikasi Intellectual Capital Terhadap Financial Performance, Growth dan Market Value; Studi Empiris Dengan Pendekatan Simplistic Specification. SNA XIII. Purwokerto.

Starovic, et al. 2003. Handbook for Chartered Institute of Management Accountants. Published by Chartered Institute of Management Accountants.

Stevens, James P..2009. Applied Multivariate Statistics For The Social Sciences Fifth Edition. Routledge Taylor \& Francis Group: London.

Tan, H.P., D. Plowman, P. Hancock. 2007. Intellectual Capital and Financial Returns of Companies. Journal of Intellectual Capital. Vol. 8 No. 1. pp. 76-95.

Ulum, Ihyaul, et al. 2008. Intellectual Capital dan Kinerja Keuangan Perusahaan; Suatu Analisis dengan Pendekatan Partial Least Squares. SNA XI. Pontianak. 